\title{
СТАН СИСТЕМИ ГІДРОГЕН СУЛЬФІДУ ПЕЧІНКИ ЩУРІВ ПРИ ЕКСПЕРИМЕНТАЛЬНІЙ НЕФРОПАТІЇ ЗА УМОВ ВВЕДЕННЯ МЕЛАТОНІНУ
}

\section{Стан системи гідроген сульфіду печінки щурів при експериментальній нефропатії за умов введення мелатоніну}

\section{І. О. Коляник, І. В. Геруш}

Буковинський державний медичний університет, м. Чернівці

Резюме. Метаболічні порушення, що виникають при нефропатії, супроводжуються продукцією вільних радикалів, що призводить до структурно-срункціональних порушень клітинних мембран різних органів і систем, у тому числі й печінки. Гідроген сульфрід $\left(\mathrm{H}_{2} \mathrm{~S}\right)-$ че газотрансмітер і важлива сигнальна молекула, що регулює безліч фрізіологічних та патофрізіологічних процесів. Мелатонін, як гормон епіфріза, володіє імуностимулюючими, детоксикаційними та антиоксидантними властивостями. Однак залишаються нез'ясованими всі механізми дії мелатоніну, зокрема його вплив на систему гідроген сульфріду при нефропатії.

Мета дослідження - з'ясувати вплив мелатоніну на стан системи гідроген сульфріду в печінці щурів за умов експериментальної нефрропатії.

Матеріали і методи. Експеримент проведено на 84 нелінійних щурах-самцях масою 0,16-0,18 ке. Експериментальну нефропатію моделювали за допомогою одноразового внутрішньочеревного введення фолієвої кислоти в дозі 250 мг/кг маси тіла. Мелатонін вводили інтрагастрально упродовж 7-ми днів після моделювання нефропатії в дозі 10 мг/ке. У постмітохондріальній фрракції печінки щурів визначали продукцію та концентрацію гідроген сульфріду, а також активність $\mathrm{H}_{2} \mathrm{~S}$-генеруючих ензимів: цистатіонін-у-ліази (CSE), цистатіонін- $\beta$-синтази (CBS) та цистеїнамінотрансфоерази (САT).

Результати. При експериментальній нефропатіі встановлено зниження продукції та концентрації $\mathrm{H}_{2} \mathrm{~S}$ на 27,9 \% і 45,2 \% відповідно, а також зниження активносmі $\mathrm{H}_{2} \mathrm{~S}$-продукуючих ензимів: CSE - на 31,7 \%, CBS - на 32,1 \% та CAT - на 32,7 \% відповідно порівняно з групою контрольних тварин. Введення мелатоніну сприяло підвищенню $\mathrm{H}_{2} \mathrm{~S}$-продукціїта концентраціїна 20,9\% і33,0\%, а також активності $\mathrm{H}_{2} \mathrm{~S}$-продукуючих ензимів CBS ma САT на 23,7 \% і 25,4 \% відповідно, порівняно з показниками тварин із нефропатією, але все ще достовірно відрізнялося від показників контрольних тварин.

Висновки. Нефропатія призводить до зниження концентрації та продукції $\mathrm{H}_{2} \mathrm{~S}$ у печінці щурів, через
The state of the liver hydrogen sulfide system in rats with experimental nephropathy under conditions of melatonin introduction

I. O. Kolianyk, I. V. Gerush

Bukovinian State Medical University, Chernivtsi

e-mail: gerushiv@ukr.net

Summary. Metabolic disorders occurring with nephropathy are associated with the production of free radicals resulting in structural-functional disturbances of the cellular membranes of different organs and systems including the liver. Hydrogen sulfide $\left(\mathrm{H}_{2} \mathrm{~S}\right)$ is a gas transmitter and an important signal molecule regulating a number of physiological and pathophysiological processes. Melatonin as a hormone produced by the pineal body possesses immune stimulating, disintoxicating and antioxidant properties. Meanwhile, all the mechanisms of melatonin action still remain uncertain, in particular its effect on the hydrogen sulfide system with nephropathy.

The aim of the study - to determine melatonin effect on the hydrogen sulfide system state in the liver of rats under conditions of experimental nephropathy.

Materials and Methods. The experiment was carried out on 84 nonlinear male rats with the body weight of $0.16-0.18 \mathrm{~kg}$. Experimental nephropathy was simulated by means of a single introduction of folic acid into the peritoneum in the dose of $250 \mathrm{mg} / \mathrm{kg}$ of the body weight. Melatonin was introduced into the stomach during 7 days in the dose of $10 \mathrm{mg} / \mathrm{kg}$ after nephropathy was simulated. The production and concentration of hydrogen sulfide, activity of $\mathrm{H}_{2} \mathrm{~S}$ generating enzymes such as cystathionine $y$-lyase (CSE), cystathionine $\beta$ - synthase (CBS) and cysteine aminotransferase (CAT) were determined in the post-mitochondrial liver fraction of rats.

Results. With experimental nephropathy the production and concentration of $\mathrm{H}_{2} \mathrm{~S} 27.9 \%$ and $45.2 \%$ decreased respectively, and the activity of $\mathrm{H}_{2} \mathrm{~S}$-generating enzymes decreased as well: CSE by $31.7 \%$, CBS by $32.1 \%$ and CAT by $32.7 \%$, in comparison with the group of control animals. Melatonin introduction promoted increase of $\mathrm{H}_{2} \mathrm{~S}$ production and concentration by $20.9 \%$ and $33.0 \%$, as well as the activity of $\mathrm{H}_{2} \mathrm{~S}$-producing enzymes CBS and CAT by $23.7 \%$ and $25.4 \%$ respectively, in comparison with the parameters of animals with nephropathy, but they differed reliably from the parameters of the control animals.

Conclusions. Nephropathy leads to decrease of the concentration and production of $\mathrm{H}_{2} \mathrm{~S}$ in the liver of animals 
пригнічення $\mathrm{H}_{2} \mathrm{~S}$-продукуючої активності ензимів, що генерують $\mathrm{H}_{2} \mathrm{~S}$. Введення мелатоніну сприяло підвищенню вмісту гідроген сульфріду як за рахунок підвищення активності CBS та CAT, так, ймовірно, і за рахунок безпосередньої участі мелатоніну в знешкодженні вільних радикалів та зниженні окиснювальної модифрікації протеїнів, зокрема і досліджуваних ензимів.

Ключові слова: гідроген сульфрід; нефрропатія; печінка; мелатонін.

\section{ВСТУП}

Одна з актуальних проблем у сучасній медицині - захворювання нирок. Метаболічні порушення, що виникають при нефропатії, супроводжуються продукцією вільних радикалів, що призводить до структурно-фрункціональних порушень клітинних мембран та посилення процесів пероксидного окиснення ліпідів, що спричинятиме ушкодження різних органів і систем, у тому числі й печінки.

Добре відомо, що печінка бере участь у метаболізмі глюкози та ліпідів, антиоксидантному захисті та метаболізмі ксенобіотиків. Також вона забезпечує розщеплення сірковмісних амінокислот та утворення гідроген сульфіду $\left(\mathrm{H}_{2} \mathrm{~S}\right)$ [1].

За останнє десятиліття гідроген сульорід зацікавив вчених як газотрансмітер та важлива сигнальна молекула поряд із монооксидом вуглецю (СО) та монооксидом азоту (NO) [2, 3]. Він утворюється в результаті різноманітних фрерментативних та нефрерментативних реакцій, і регулює безліч фрізіологічних та патофрізіологічних процесів у різноманітних клітинах та тканинах. Гідроген сульфрід діє як судиннорозширювальний, цитопротекторний та протизапальний засіб при низьких концентраціях, але також здатний викликати цитотоксичну дію при більш високих концентраціях.

У наш час $\mathrm{H}_{2} \mathrm{~S}$ залишається предметом інтенсивних досліджень, направлених на те, щоб краще зрозуміти його біологічну роль та можливості застосування для досягнення терапевтичного есректу.

Мелатонін, як гормон епіфріза, володіє широким спектром фрізіологічних фрункцій: регулює циркадіанні ритми, артеріальний тиск, володіє протипухлинною, імуностимулюючою, детоксикаційною та антиоксидантною діями. Оскільки мелатонін легко проникає через біологічні мембрани, то його ефекти проявляються в кожній клітині організму [4]. Проте залишаються нез'ясованими всі механізми дії мелатоніну, зокрема, його вплив на систему гідроген сульфіду при нефропатії.

Метою дослідження було вивчити вплив ме-

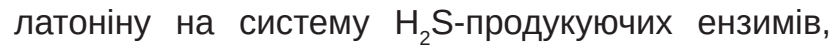
концентрацію та продукцію $\mathrm{H}_{2} \mathrm{~S}$ у печінці щурів за умов експериментальної нефрропатії. due to inhibition of $\mathrm{H}_{2} \mathrm{~S}$-producing activity of enzymes generating $\mathrm{H}_{2} \mathrm{~S}$. Melatonin introduction promoted increase of hydrogen sulfide content both at the expense of increased activity of CBS and CAT, and probably at the expense of a direct participation of melatonin in neutralization of free radicals and reduction of protein oxidative modification, and the examined enzymes in particular.

Key words: hydrogen sulfide; nephropathy; liver; melatonin.

\section{МАТЕРІАЛИ I МЕТОДИ}

Експеримент проводили на 84 білих статевозрілих щурах-самцях масою 0,16-0,18 кг. Моделювання нефропатії здійснювали шляхом одноразового внутрішньочеревного введення фролієвої кислоти (Sigma-Aldrich, США ) у дозі 250 мг/кг маси тіла [5]. Тварин поділили на 3 групи: перша - інтактна група тварин; друга - експериментальні тварини, із змодельованою нефропатією (7 днів); третя - тварини, яким на тлі моделювання експериментальної нефропатії щоденно вводили мелатонін (Sigma-Aldrich, USA) в дозі 10 мг/кг маси тіла внутрішньошлунково упродовж 7 днів.

Усі маніпуляції з експериментальними тваринами проведені 3 дотриманням основних положень Закону України «Про захист тварин від жорстокого поводження» (2006), Директиви Ради Європи 2010/63 EU щодо експериментів на тваринах.

Активність цистатіонін-у-ліази (CSE), цистатіонін-ß-синтази (CBS) та цистеїнамінотрансфрерази (САТ) оцінювали за кількістю утвореного гідроген сульфіду [6] в постмітохондріальній фрракції гомогенатів печінки. Продукцію та концентрацію гідроген сульфріду визначали спектрофротометричним методом, що ґрунтується на реакції між сульоріданіоном та N, N-диметилпарафенілендіаміном у кислому середовищі в присутності іонів $\mathrm{Fe}^{3+}[7,8]$. Концентрацію протеїну визначали за методом Лоурі [9]. Вимірювання проводили на спектрофротометрі Agilent Cary 60.

Статистичну обробку отриманих даних здійснювали за допомогою непараметричного критерію Вілкоксона. Результати вважали достовірними при $р<0,05$.

\section{РЕЗУЛЬТАТИ Й ОБГОВОРЕННЯ}

За умов експериментальної нефропатії спостерігалося зниження концентрації гідроген сульфріду (рис. 1) в печінці щурів на 45,2 \% та продукції гідроген сульфіду (рис. 2) на 27,9 \%, що супроводжувалося і зниженням активності $\mathrm{H}_{2} \mathrm{~S}-$ синтезуючих ензимів (рис. 3): CSE - на 31,7 \%, CBS - на 32,1\%, CAT - на 32,7 \% порівняно 3 показниками групи контрольних тварин.

$\mathrm{H}_{2} \mathrm{~S}$ - ендогенний газотрансмітер, що утворюється в результаті ензематичних та неензематичних 


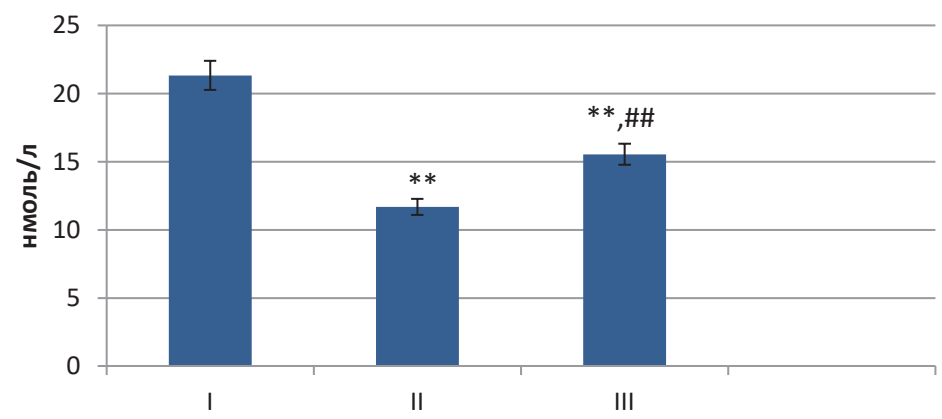

Рис. 1. Вплив мелатоніну на концентрацію гідроген сульфіду в печінці щурів за умов експериментальної нефропатії.

Пимітки: I - контроль (n=36); II- несропатія (n=24); III - нефропатія+мелатонін (n=24); дані представлено у вигляді середня土стандартна помилка середньої (M $\pm \mathrm{m})$.

1) ** - статистично значущі відмінності порівняно з показниками контрольної групи тварин $(p<0,01)$;

2) - статистично значущі відмінності порівняно з показниками щурів із нефропатією $(p<0,01)$.

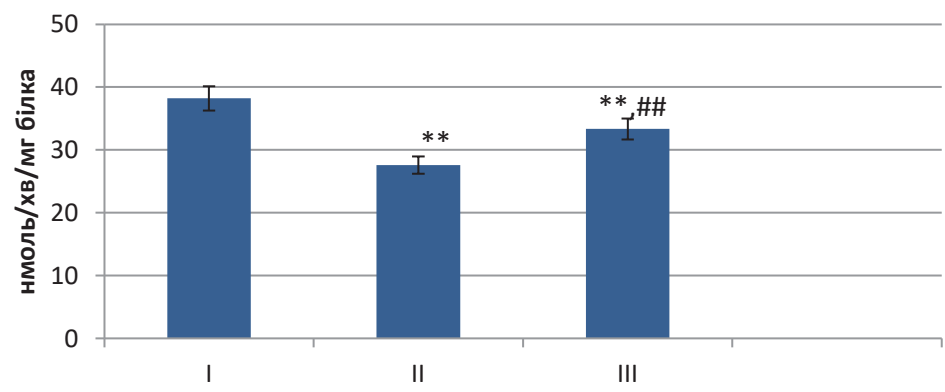

Рис. 2. Вплив мелатоніну на продукцію гідроген сульфіду в печінці щурів за умов експериментальної нефропатії.

Примітки: I - контроль (n=36); II - несропатія (n=24); III - несропатія+ мелатонін (n=24); дані представлено у вигляді середня

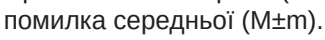

1) ** - статистично значущі відмінності порівняно з показниками контрольної групи тварин $(p<0,01)$;

2) - статистично значущі відмінності порівняно з показниками щурів із нефропатією $(p<0,01)$.

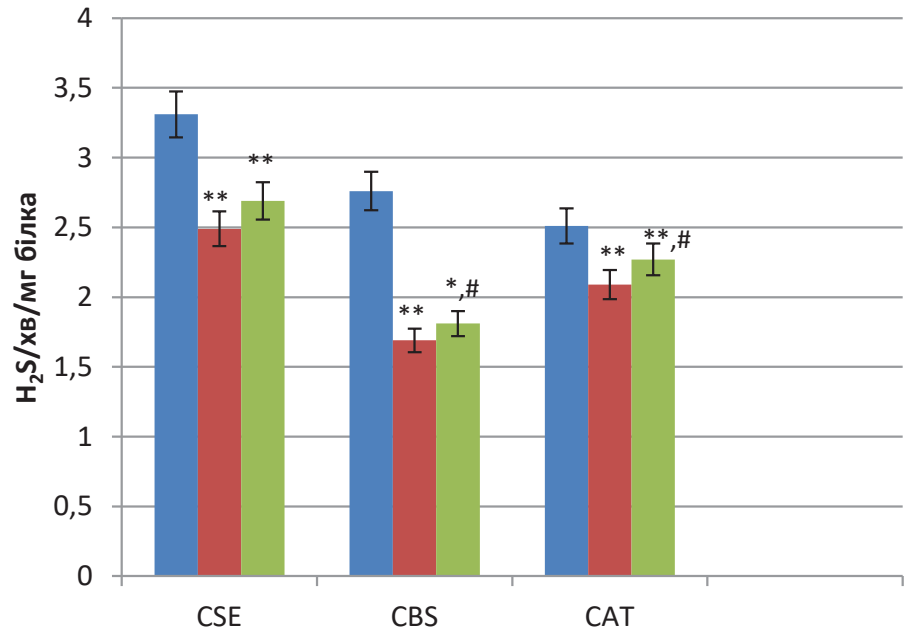

\section{Контроль \\ Нефропатія \\ - Нефропатія+мелатонін}

Рис. 3. Вплив мелатоніну на активність $\mathrm{H}_{2}$ S-продукуючих ензимів у печінці щурів за умов експериментальної нефропатії.

Примітки: CSE - цистатіонін-у-ліаза; CBS - цистатіонін- $\beta$-синтаза; CAT - цистеїнамінотрансфрераза; дані представлено у вигляді середня $\mathbf{с т а н д а р т н а ~ п о м и л к а ~ с е р е д н ь о і ̈ ~}(M \pm m)$.

$1)$ * - статистично значущі відмінності порівняно з показниками контрольної групи тварин $(p<0,05)$;

2) \# - статистично значущі відмінності порівняно з показниками щурів із нефропатією $(p<0,05)$;

3) ** - статистично значущі відмінності порівняно з показниками контрольної групи тварин $(p<0,01)$

4) - статистично значущі відмінності порівняно з показниками щурів із нефропатією $(p<0,01)$. 
реакцій. У випадку використання неензиматичних систем, персульфіди, тіосульфрати та полісульфіди можуть перетворюватися в ендогенний гідроген сульсрід в присутності NADPH ${ }^{+}$та $\mathrm{NADH}^{+}$[10]. У процесі ензиматичного шляху CSE та CBS - цитозольні піридоксальзалежні ензими, призводять до утворення гідроген сульфіду з використанням L-цистеїну та гомоцистеїну в якості основних субстратів. САТ також використовує в якості субстрату цистеїн та $\alpha$-кетоглутарат, з утворенням проміжного продукту 3-меркаптопірувату, перетворення якого призводить до продукції гідроген сульфріду $[11,12]$. Більша частина САТ локалізується в мітохондріях, оскільки саме там концентрація L-цистеїну в 3 рази вища, ніж в цитоплазмі $[10,13]$.

$\mathrm{H}_{2} \mathrm{~S}$ здатний підтримувати мітохондріальні функції, пригнічуючи утворення активних фрорм оксигену (АФО), та цим самим виявляючи антиоксидантні ефекти та сприяти репарації мітохондріальної ДНК шляхом прямої взаємодії з ензимами репарації ДНК [2].

Зміни в системі $\mathrm{H}_{2} \mathrm{~S}$ при експериментальній нефрропатії можуть призводити до порушення внутрішньоклітинного метаболізму, фрормування нативної структури білків, синтезу глутатіону та інших важливих біологічно активних сполук.

Введення мелатоніну упродовж 7 днів сприяло підвищенню показників $\mathrm{H}_{2} \mathrm{~S}-п р о д у к ц і і ̈ ~ т а ~ \mathrm{H}_{2} \mathrm{~S}-к о \mathrm{H}^{-}$ центрації у печінці щурів на 20,9 та 33,0 \% відповідно, порівняно з показниками тварин із нефропатією, але все ще достовірно відрізнялося від показників контролю. Підвищення рівня гідроген сульфріду, на нашу думку, досягалося за рахунок зростання гідроген сульфрідпродукувальної активності CBS на 23,7 \% та САТ - на 25,4 \% порівняно з показниками тва-

\section{СПИСОК ЛІТЕРАТУРИ}

1. Hydrogen sulfide as a novel regulatory factor in liver health and disease / D. D. Wu, D. Y. Wang, H. M. Li [et al.] // Oxidative Medicine and Cellular Longevity. - 2019. No. 2019.

2. Szabo C. International Union of Basic and Clinical Pharmacology. CII: Pharmacological Modulation of H2S Levels: H2S Donors and H2S Biosynthesis Inhibitors / C. Szabo, A. Papapetropoulos // Pharmacological Reviews. - 2017. - No. 69 (4). - P. 497-564.

3 . Wei W. The content of hydrogen sulfide in plasma of cirrhosis rats combined with portal hypertension and the correlation with indexes of liver function and liver fibrosis / W. Wei, C. Wang, D. Li. // Exp. Ther. Med. - 2017. - No. 14 (5). - P. 5022-5026.

4. Melatonin: Pharmacology, functions and therapeutic benefits / S. Tordjman, S. Chokron, R. Delorme [et al.] // Current Neuropharmacology. - 2017. - No. 15 (3). P. 434-443.

5. Folic acid induces acute renal failure (ARF) by enhancing renal prooxidant state / A. Gupta, V. Puri, рин із нефропатією. Однак показники активності ензимів, що беруть участь у генерації $\mathrm{H}_{2} \mathrm{~S}$ під впливом введення мелатоніну, все ще достовірно відрізнялися від значень контрольних тварин.

Позитивний вплив мелатоніну на систему $\mathrm{H}_{2} \mathrm{~S}$ можливий за рахунок здатності мелатоніну безпосередньо перехоплювати вільні радикали, знижуючи окиснювальний стрес, та забезпечуючи есрективне фрункціонування дихального ланцюга мітохондрій [14]. Також $\mathrm{H}_{2} \mathrm{~S}$ збільшує активність цистин/глутаматного антипортера, тим самим збільшуючи транспорт цистину в клітини, де той, у свою чергу, відновлюється до цистеїну та включається в глутатіон - основний внутрішньоклітинний антиоксидант [15].

Дані зміни також можуть свідчити про здатність мелатоніну підвищувати вміст $\mathrm{H}_{2} \mathrm{~S}$, який сам здатний забезпечувати захист клітин від окиснювального стресу та сприяє підвищенню рівня відновленого глутатіону [15]. А цистеїн, що міститься в складі глутатіону, у свою чергу, бере участь у метаболізмі гідроген сульфріду.

\section{ВИСНОВКИ}

Неорропатія призводить до зниження концентрації та продукції $\mathrm{H}_{2} \mathrm{~S}$ у печінці щурів, через пригнічення $\mathrm{H}_{2} \mathrm{~S}$-генеруючої активності ензимів: CSE, CBS та CAT.

Введення мелатоніну сприяло підвищенню вмісту гідроген сульфріду як за рахунок підвищення гідроген сульорідпродукувальної активності CBS та CAT, так, ймовірно, і за рахунок безпосередньої участі у знешкодженні вільних радикалів та зниженні окиснювальної модисрікації протеїнів, зокрема і досліджуваних ензимів.

R. Sharma, R. Puri. // Exper. and Toxic. Pathol. - 2012. No. 64 (3) - P. 225

6. Stipanuk M. H. Characterization of the enzymic capacity for cysteine desulphhydration in liver and kidney of the rat / M. H. Stipanuk, P. W. Beck. // Biochem. J. - 1982 (2). - No. 206. - P. 267-277.

7. The vasorelaxant effect of $\mathrm{H} 2 \mathrm{~S}$ as a novel endogenous KATP channel opener / W. Zhao, J. Zhang, Y. Lu, R. Wang // European Molecular Biology Organization. 2001. - No. 20. - P. 6008-6016.

8. Siegel L. M. A direct microdetermination for sulfide / L. M. Siegel // Analytical Biochemistry. - 1965. - No. 11. P. 126-132.

9. Protein measurement with the Folin phenol reagent / O. H. Lowry, N. J. Rosebrough, A. L. Farr, R. J. Randall // J. Biol. Chem. - 1951. - No. 193 (1). - P. 265-275.

10. Implications of hydrogen sulfide in liver pathophysiology: Mechanistic insights and therapeutic potential / H. J. Sun, Z. Y. Wu, X. W. Nie [et al.] // Journal of Advanced Research. - 2021. - No. 27. - P. 127-135. 
11. Loiselle J. J. Hydrogen sulfide and hepatic lipid metabolism - a critical pairing for liver health / J. J. Loiselle, G. Yang, L. Wu // Br. J. Pharmacol. - 2020. - No. 177. - P. 757-768.

12. Changes in hydrogen sulfide in rats with hepatic cirrhosis in different stages / N. Zhang, Y. Zheng, W. Chen [et al.] // Curr. Med. Sci. - 2017. - No. 37 (5). - P. 705-710.

13. Kimura $\mathrm{H}$. Signaling molecules: hydrogen sulfide and polysulfide / H. Kimura // Antioxidants \& Redox Signaling. - 2015. - No. 22 (5). - P. 362-376.

\section{REFERENCES}

1. Wu DD, Wang DY, Li HM, Guo JC, Duan SF, Ji XY. Hydrogen sulfide as a novel regulatory factor in liver health and disease. Oxidative Medicine and Cellular Longevity. 2019

2. Szabo C, Papapetropoulos A. International Union of Basic and Clinical Pharmacology. CII: Pharmacological Modulation of H2S Levels: H2S Donors and H2S Biosynthesis Inhibitors. Pharmacological reviews. 2017;69(4): 497-564

3. Wei W, Wang C, Li D. The content of hydrogen sulfide in plasma of cirrhosis rats combined with portal hypertension and the correlation with indexes of liver function and liver fibrosis. Exp Ther Med. 2017;14(5): 5022-26.

4. Tordjman S, Chokron S, Delorme R, Charrier A, Bellissant E, Jaafari $N$, et al. Melatonin: Pharmacology, Functions and Therapeutic Benefits. Current neuropharmacology. 2017;15(3): 434-43. Available from: https://doi.org/1 $0.2174 / 1570159 \times 14666161228122115$.

5. Gupta A, Puri V, Sharma R, Puri R. Folic acid induces acute renal failure (ARF) by enhancing renal prooxidant state. Exper and Toxic Pathol. 2012;64(3): 225-32.

6. Stipanuk MH, Beck PW. Characterization of the enzymic capacity for cysteine desulphhydration in liver and kidney of the rat. Biochem J. 1982;206(2): 267-77.

7. Zhao W, Zhang J, Lu Y, Wang R. The vasorelaxant effect of $\mathrm{H} 2 \mathrm{~S}$ as a novel endogenous KATP channel opener. EMBO J. 2001;20: 6008-16.
14. Luhinich N. Effects of 7-day melatonin introduction on the hydrogen sulfide production and glutathione system in the liver of alloxan induced diabetic rats. / N. Luhinich, I. Gerush // Georgian Med. News. - 2019. - No. 289. P. 135-139.

15. Kimura $\mathrm{H}$. Production and physiological effects of hydrogen sulfide / H. Kimura // Antioxidants \& Redox Signaling. - 2014. - No. 20 (5). - P. 783-793.

8. Siegel LM. A direct microdetermination for sulfide. Analytic.Biochem. 1965;11: 126-32.

9. Lowry $\mathrm{OH}$, Rosebrough NJ, Farr AL, Randall RJ. Protein measurement with the Folin phenol reagent. J Biol Chem. 1951;193(1): 265-75.

10. Sun $\mathrm{HJ}$, Wu ZY, Nie XW, Wang XY, Bian JS. Implications of hydrogen sulfide in liver pathophysiology: Mechanistic insights and therapeutic potential. J Advanced Research. 2021;27: 127-35.

11. Loiselle JJ, Yang G, Wu L. Hydrogen sulfide and hepatic lipid metabolism - a critical pairing for liver health. Br J Pharmacol. 2020;177(4): 757-68.

12. Zhang N, Zheng Y, Chen WG, Li R, Song LX, Xu LH, et al. Changes in hydrogen sulfide in rats with hepatic cirrhosis in different stages. Curr Med Sci. 2017;37(5): 705-10. Available from: https://doi.org/10.1007/s11596-017-1792-y.

13. Kimura $\mathrm{H}$. Signaling molecules: hydrogen sulfide and polysulfide. Antioxidants \& redox signaling. 2015;22(5): 362-76.

14. Luhinich N, Gerush I. Effects of 7-day melatonin introduction on the hydrogen sulfide production and glutathione system in the liver of alloxan induced diabetic rats. Georg Med News. 2019;289: 135-9.

15. Kimura $H$. Production and physiological effects of hydrogen sulfide. Antioxidants \& redox signaling. 2014;20(5): 783-93. 